\title{
Appendiceal Carcinoma pTO TNM Finding v8
}

National Cancer Institute

\section{Source}

National Cancer Institute. Appendiceal Carcinoma pT O TNM Finding v8. NCI Thesaurus.

Code C134056.

Appendiceal carcinoma with no evidence of primary tumor. (from AJCC 8th Ed.) 